\title{
Growth, Yield attributes and Yield of Indian Mustard [Brassica juncea (L.) Czern \& Coss] as Influenced by Irrigation and Nitrogen Levels
}

\author{
Debashis Bindhani, S.B. Goswami, Amit Kumar*, \\ Gaurav Verma and Pratishruti Behera
}

Department of Agronomy, Bidhan Chandra Krishi Viswavidyalaya, Mohanpur, West Bengal-741 252, India

*Corresponding author

\section{A B S T R A C T}

\section{Keywords}

Growth, Hybrid mustard, Irrigation, Nitrogen levels, Yield attributes, Yield

\section{Article Info}

\section{Accepted:}

14 June 2020

Available Online:

10 July 2020
A field experiment was conducted during rabi season of 2017-18 at Central Research Farm, Gayespur, Nadia, under Bidhan Chandra Krishi Viswavidyalaya, Mohanpur, West Bengal to assess the performance of hybrid mustard as influenced by irrigation and nitrogen levels. The experiment comprised of 9 treatment combination in split plot design with three replications. The result of experiment revealed that the growth and yield of hybrid mustard was significantly influenced by irrigation and nitrogen management in low land rice ecosystem. The maximum plant height and crop growth rate was noticed with IW/CPE $=1.2$ and $120 \mathrm{~kg} \mathrm{~N} / \mathrm{ha}$ and the lowest was recorded under IW/CPE $=0.8$ and $40 \mathrm{~kg}$ $\mathrm{N} / \mathrm{ha}$. The highest value of dry matter accumulation was registered with $\mathrm{IW} / \mathrm{CPE}=1.0$ and $120 \mathrm{~kg} \mathrm{~N} / \mathrm{ha}$ and the lowest was recorded under IW/CPE $=1.0$ and $80 \mathrm{~kg} \mathrm{~N} / \mathrm{ha}$. The maximum number of branches was recorded under IW/CPE $=1.2$ and the minimum was observed with IW/CPE $=0.8$. Among the nitrogen levels, number of branches was found the highest with $120 \mathrm{~kg} \mathrm{~N} / \mathrm{ha}$ and the lowest was recorded with $40 \mathrm{~kg} \mathrm{~N} / \mathrm{ha}$. The maximum number of siliqua per plant was noticed under IW/CPE $=1.2$ and the lowest was recorded with IW/CPE $=1.0$ and $40 \mathrm{~kg} \mathrm{~N} / \mathrm{ha}$. The number of seeds per siliqua was found the highest with $\mathrm{IW} / \mathrm{CPE}=1.2$ and the lowest was obtained with IW/CPE=0.8. The maximum test weight was noticed with IW/CPE $=1.0$ and $120 \mathrm{~kg} \mathrm{~N} / \mathrm{ha}$ and the lowest was recorded under IW/CPE $=0.8$ and $40 \mathrm{~kg} \mathrm{~N} / \mathrm{ha}$. The maximum seed yield was achieved in IW/CPE=1.0 with $120 \mathrm{~kg}$ nitrogen/ha and the minimum was noted with IW/CPE $=1.2$ with $40 \mathrm{~kg}$ N/ha. The maximum biological yield was registered in IW/CPE $=0.8$ with $120 \mathrm{~kg}$ nitrogen $/ \mathrm{ha}$ and the lowest was recorded with IW/CPE=1.2 with $40 \mathrm{~kg}$ nitrogen $/ \mathrm{ha}$.

\section{Introduction}

Indian mustard is the member of brassica group and commonly known as rai or laha and grown under a wide range of agro climatic conditions. It, have a significant role in Indian agriculture since almost each part of the plant is consumed either by human beings or animals depending upon the crop and its growth stage. Indian mustard is an important oilseed crop of the Indian subcontinent and contributes more than $80 \%$ of the total rapeseed-mustard production of the country. The oil content of Indian mustard is varied 
between 30 to $45.7 \%$. The seed and oil are used as condiment in the preparation of pickles and for flavouring curries and vegetables. The oil is utilized for human consumption throughout the northern India, in cooking and frying purposes. Among the seven edible oilseed cultivated in India, rapeseed-mustard (Brassica spp.) contributes $28.6 \%$ in the total production of oilseeds. India is the fourth largest oilseed economy in the world. European Union is the leading producer of mustard seed in the world accounting for $35 \%$ of the world production followed by Canada (21\%), China (22\%) and India (11\%) (GOI, 2018). In India, it is the second most important edible oilseed after groundnut sharing $27.8 \%$ in the India's oilseed economy. The share of oilseeds is $14.1 \%$ out of the total cropped area in India, rapeseed-mustard accounts for $3 \%$ of it. The global production of rapeseed-mustard and its oil is around 38-42 and 12-14 mt, respectively and India contributes about $28.3 \%$ and $19.8 \%$ in world acreage and production. In India, mustard is mainly grown in North West parts of India. Rajasthan and Uttar Pradesh are the major producing States in the country. The production from Rajasthan is highly monsoon dependent. The other significant producers are Madhya Pradesh, Haryana, Gujarat, West Bengal and Assam. Rajasthan is the most giant rapeseed-mustard growing state and alone contributes $43 \%$ of the total mustard seed production in India (GOI, 2018). The productivity of mustard in India is very low with an average yield about 1.0 ton/ha compared to world average. The major constraint attributing to low production of mustard are scare and untimely water supply, poor fertility status of soil and weed management. General practices of growing it crop under fields are kept fallow during rainy season to conserve moisture and farmers generally give one or two irrigations depending on the availability of water even though the crop grown on conserved moisture. Scientific schedule based on IW/CPE ratio is difficult for farmer to undertaken. Yadav et al., (2010) observed that when water supply at the most critical growth stages (at flower initiation stage and siliquae development stage) achieved the maximum growth and yield attributes. Thus, scheduling water supply at the most critical growth stage would boost plant production efficiency on one-hand and water economy on the other hand. If crop is generally grown on marginal lands with poor fertility status and therefore it suffers from nutrient stress. Among three primary nutrients $(\mathrm{N}, \mathrm{P}$ and $\mathrm{K})$ rapeseed mustard a cruciferous crop, responds remarkably well to nitrogen fertilization mainly due to its exhaustive nature and deep rooting system. Presently, most of the farmers are using exhaustive high yielding varieties of mustard that have lead to heavy withdrawal of nutrient from the soil and fertilizer consumption remained much below as compared to removal. Application of nitrogen enhances growth and development of crop and results in higher seed yield. Despite the sufficient availability of irrigation water and fertilizer nutrients, higher yields are realised only when the selection of suitable cultivars under the particular agro climatic conditions are made. Nitrogen $(\mathrm{N})$ is the most important nutrient, and being a constituent of protoplasm and protein, it is involved in several metabolic processes that strongly influence growth, productivity and quality of crops (Kumar et al., 2000). The $\mathrm{N}$ fertilizer application accounts for significant crop production cost. Rapeseed-mustard group of crops have relatively high demand for $\mathrm{N}$ than many other crops owing to larger $\mathrm{N}$ content in seeds and plant tissues (Malagoli et al., 2005). Yield increases in Indian mustard at various locations in India have been reported with application of $\mathrm{N}$ as high as $150 \mathrm{~kg} / \mathrm{ha}$ or more (Singh et al., 2008). Brassicas are known to remove higher amount of $\mathrm{N}$ until flowering with relatively lower amount taken up during 
reproductive growth phase (Bhari et al., 2000). Poor translocation of $\mathrm{N}$ from vegetative parts to seed during reproductive growth results in low nitrogen use efficiency. Since N fertilizers are costly, poor NUE is of great concern and therefore, attempts are needed to improve the contribution of applied $\mathrm{N}$ to production of grain and this approach will reduce the environmental and production costs in agriculture. Indian mustard is particularly being deep rooted and are able to utilize the soil moisture and nutrient lower layers of the soil. Therefore, they are mostly grown under rainfed condition at residual soil moisture on marginal and sub marginal land. However, crop under such condition result in poor yield. Several agronomical manipulations are needed to harness the maximum yield potential depending on the climatic and resource management. Irrigation and fertility levels influence to a great extent of growth, yield attributes and yield (Bharati et al., 2003). Irrigation requirement of mustard varies with crop conditions, moisture storage in the soil profile and prevailing weather condition of the area. Nutrient management is also most important parameter effecting the growth and productivity of mustard. Keeping in view the above facts the experiment was conducted on "growth and productivity of hybrid mustard as influenced by irrigation and nitrogen management".

\section{Materials and Methods}

A field experiment was conducted during rabi season of 2017-18 at Central Research Farm, Gayespur, Nadia, under Bidhan Chandra Krishi Viswavidyalaya, Mohanpur, West Bengal is situated at $22^{\circ} 56^{\prime} \mathrm{N}$ latitude and $88^{\circ} 32^{\prime}$ E longitude and 9.75 meter above MSL. The soil of experimental field was sandy loam in texture, bulk density (1.53 $\left.\mathrm{Mg} / \mathrm{m}^{3}\right), \mathrm{pH} 7.1$, EC $(0.16 \mathrm{dS} / \mathrm{m})$, medium is organic carbon $(0.58 \%)$ and low is available $\mathrm{N}(228 \mathrm{~kg} / \mathrm{ha})$, medium in available $\mathrm{P}(13.1$ $\mathrm{kg} / \mathrm{ha}$ ) and available K (198 kg/ha). The experiment was comprised of 9 treatment combinations, which comprised of 3 treatments $\quad\left[\mathrm{I}_{1} \quad(\mathrm{IW} / \mathrm{CPE} \quad\right.$ ratio $=0.8), \mathrm{I}_{2}$ $\left(\mathrm{IW} / \mathrm{CPE}\right.$ ratio=1.0), $\mathrm{I}_{3}(\mathrm{IW} / \mathrm{CPE}$ ratio=1.2)] in main plot and 3 treatments $\left[\mathrm{N}_{1}\left(40 \mathrm{~kg} \mathrm{~N}\right.\right.$ ha ${ }^{-}$ $\left.\left.{ }^{1}\right), \mathrm{N}_{2}\left(80 \mathrm{~kg} \mathrm{~N} \mathrm{ha}^{-1}\right), \mathrm{N}_{3}\left(120 \mathrm{~kg} \mathrm{~N} \mathrm{ha}^{-1}\right)\right]$ in sub plots, laid out in split plot design with three replications. The fertilizer nutrients were supplied through urea, diammonium phosphate (DAP) and muriate of potash (MOP). Half dose of nitrogen and full dose of phosphorus and potassium as per treatment were applied as basal and remaining dose of nitrogen was applied at first irrigation. The Hybrid mustard cultivar PAN 70 was sown at $30 \times 15 \mathrm{~cm}$ crop geometry with a seed rate of 4-5 kg/ha apart during the second week of November. Fallow the standard procedures and observations were recorded on growth, yield attributes and yield. Plant height at different stages of crop growth were recorded by five randomly selected plants from sampling rows and measure the ground to top leaf of plant by centimeter scale and averaged them in $\mathrm{cm}$. five plants per plot were cut from the ground level from sampling row at 30, 60, 90 DAS and harvest stage. Those plants were first air-dried for 2-3 days following by ovendried at $60-65^{\circ} \mathrm{C}$ for 48 hours and dry weight was recorded in g plant $^{-1}$.

The mean crop growth rate was worked out with the following formula (Watson et al., 1952).

$\mathrm{CGR}=\left(\frac{\mathrm{W}_{2}-\mathrm{W}_{1}}{\mathrm{~T}_{2}-\mathrm{T}_{1}}\right)\left(\frac{1}{\mathrm{~S}}\right)$

Where,

$\mathrm{W}_{1}$ and $\mathrm{W}_{2}$ are dry weight ( $\mathrm{g}$ ) of plants at time $\mathrm{T}_{1}$ and $\mathrm{T}_{2}$, respectively

$\mathrm{T}_{2^{-}} \mathrm{T}_{1}$ is the interval of time in days

$\mathrm{S}$ is land area $\left(\mathrm{m}^{2}\right)$ occupied by plants 
At harvest, the number of siliqua of main shoot, primary, secondary and tertiary branches of each of the five tagged plants was counted separately, summed and finally mean was taken. Randomly ten siliqua were selected from each plot after harvesting and their length was measured and average was calculated. All the seeds of ten randomly sampled siliqua were counted and average was recorded. After completion of threshing and winnowing, a representative sample of seeds was drawn separately from the bulk produce of each treatment. With the help of electronic seed counter, 1000 seeds were counted and weight was recorded. The total biomass obtained from each net plot was threshed followed by cleaning and weighing. Seed yield, thus obtained was expressed in terms of $\mathrm{kg}$ per plot and then converted to $\mathrm{kg} / \mathrm{ha}$. The seed yield for each net plot was deducted from respective biological yield and thus the stover yield was computed and expressed in terms of $\mathrm{kg}$ per plot and then in $\mathrm{kg} / \mathrm{ha}$. The entire above ground biomass obtained from each net plot was sundried properly and after that the weight was recorded and biological yield was expressed as $\mathrm{kg} / \mathrm{ha}$. The data collected of different parameters were subjected to appropriate statistical analysis under Split Plot Design by following the procedure of ANOVA analysis of variance (SAS Software packages, SAS EG 4.3). Significance of difference between means was tested through ' $F$ ' test and the least significant difference (LSD) was worked out where variance ratio was found significant for treatment effect. The treatment effects were tested at $5 \%$ probability level for their significance.

\section{Results and Discussion}

Growth parameters (plant height, dry matter accumulation and crop growth rate)

The irrigation levels and nitrogen doses had significant effect on plant height, dry matter accumulation and crop growth rate of hybrid mustard. At 30 DAS maximum plant height $(37 \mathrm{~cm})$ was noticed with $\mathrm{IW} / \mathrm{CPE}=1.2$ and $120 \mathrm{~kg} \mathrm{~N} /$ ha followed by IW/CPE $=1.0$ and 80 $\mathrm{kg} \mathrm{N} / \mathrm{ha}$ and the lowest plant height was recorded $(26 \mathrm{~cm})$ under $\mathrm{IW} / \mathrm{CPE}=0.8$ and application of $40 \mathrm{~kg} \mathrm{~N} / \mathrm{ha}$. The maximum plant height $(133 \mathrm{~cm})$ at 60 DAS was noticed with IW/CPE $=1.2$ and $120 \mathrm{~kg} \mathrm{~N} /$ ha followed by IW/CPE $=1.0$ and $80 \mathrm{~kg} \mathrm{~N} / \mathrm{ha}$ and the lowest plant height $(119 \mathrm{~cm})$ was observed under IW/CPE $=0.8$ and $40 \mathrm{~kg} \mathrm{~N} / \mathrm{ha}$. At 90 DAS highest plant height $(155 \mathrm{~cm})$ was registered with combination of IW/CPE $=1.0$ and $120 \mathrm{~kg} \mathrm{~N} /$ ha followed by $\mathrm{IW} / \mathrm{CPE}=1.2$ and $120 \mathrm{~kg} \mathrm{~N} / \mathrm{ha}$ and the lowest plant height was recorded $(140 \mathrm{~cm})$ with $\mathrm{IW} / \mathrm{CPE}=0.8$ and $40 \mathrm{~kg} \mathrm{~N} / \mathrm{ha}$. At harvest stage maximum plant height $(157 \mathrm{~cm})$ was noticed with combination of IW/CPE $=1.0$ and $120 \mathrm{~kg} \mathrm{~N} / \mathrm{ha}$ followed by IW/CPE=1.2 and $120 \mathrm{~kg} \mathrm{~N} / \mathrm{ha}$ and the lowest plant height $(139 \mathrm{~cm})$ was recorded with $\mathrm{IW} / \mathrm{CPE}=0.8$ and $40 \mathrm{~kg} \mathrm{~N} / \mathrm{ha}$. At 30 DAS highest value of dry matter accumulation $\left(107 \mathrm{~g} / \mathrm{m}^{2}\right)$ was recorded with combination of IW/CPE $=1.0$ and $120 \mathrm{~kg} \mathrm{~N} / \mathrm{ha}$ followed by IW/CPE $=0.8$ and $120 \mathrm{~kg} \mathrm{~N} / \mathrm{ha}$ and the lowest dry matter accumulation was recorded $\left(45.3 \mathrm{~g} / \mathrm{m}^{2}\right)$ with $\mathrm{IW} / \mathrm{CPE}=1.0$ and $80 \mathrm{~kg} \mathrm{~N} / \mathrm{ha}$. The highest dry matter accumulation $\left(567 \mathrm{~g} / \mathrm{m}^{2}\right)$ at 60 DAS was noticed with combination of IW/CPE $=1.2$ and $120 \mathrm{~kg} \mathrm{~N} / \mathrm{ha}$ followed by IW/CPE $=0.8$ and $120 \mathrm{~kg} \mathrm{~N} / \mathrm{ha}\left(542 \mathrm{~g} / \mathrm{m}^{2}\right)$ and the lowest dry matter accumulation $\left(282.5 \mathrm{~g} / \mathrm{m}^{2}\right)$ was recorded with $\mathrm{IW} / \mathrm{CPE}=0.8$ and $40 \mathrm{~kg} \mathrm{~N} / \mathrm{ha}$. At 90 DAS maximum dry matter accumulation $\left(1084.9 \mathrm{~g} / \mathrm{m}^{2}\right)$ was found with IW/CPE $=1.2$ and $120 \mathrm{~kg} \mathrm{~N} /$ ha followed by $\mathrm{IW} / \mathrm{CPE}=1.0$ and $120 \mathrm{~kg} \mathrm{~N} / \mathrm{ha}\left(967 \mathrm{~g} / \mathrm{m}^{2}\right)$ and the lowest dry matter accumulation was recorded $\left(427 \mathrm{~g} / \mathrm{m}^{2}\right)$ with $\mathrm{IW} / \mathrm{CPE}=1.0$ and 80 $\mathrm{kg} \mathrm{N} / \mathrm{ha}$. At harvesting dry matter accumulation was maximum $\left(1114 \mathrm{~g} / \mathrm{m}^{2}\right)$ with IW/CPE $=1.2$ and $120 \mathrm{~kg}$ N/ha followed by $\mathrm{IW} / \mathrm{CPE}=1.0$ and $120 \mathrm{~kg} \mathrm{~N} / \mathrm{ha}\left(1015.9 \mathrm{~g} / \mathrm{m}^{2}\right)$ 
and the lowest dry matter accumulation was recorded $\left(478.8 \mathrm{~g} / \mathrm{m}^{2}\right)$ with $\mathrm{IW} / \mathrm{CPE}=1.0$ and $80 \mathrm{~kg} \mathrm{~N} / \mathrm{ha}$. At 30-60 DAS maximum crop growth rate $\left(15.6 \mathrm{~g} / \mathrm{m}^{2} /\right.$ day $)$ was observed with IW/CPE $=1.2$ and $120 \mathrm{~kg} \mathrm{~N} /$ ha followed by IW/CPE $=0.8$ and $120 \mathrm{~kg} \mathrm{~N} / \mathrm{ha}$ and the lowest crop growth rate was recorded (7.6 $\mathrm{g} / \mathrm{m}^{2} /$ day) with IW/CPE $=0.8$ and $40 \mathrm{~kg} \mathrm{~N} / \mathrm{ha}$. The highest crop growth rate $\left(17.3 \mathrm{~g} / \mathrm{m}^{2} /\right.$ day $)$ at 60-90 DAS was with IW/CPE $=1.2$ and 120 $\mathrm{kg} \mathrm{N} / \mathrm{ha}$ followed by IW/CPE $=1.0$ and $120 \mathrm{~kg}$ $\mathrm{N} /$ ha $\left(17.1 \mathrm{~g} / \mathrm{m}^{2} /\right.$ day $)$ and the lowest Crop growth rate $\left(3.9 \mathrm{~g} / \mathrm{m}^{2} /\right.$ day $)$ was noticed under IW/CPE $=1.0$ and $80 \mathrm{~kg} \mathrm{~N} / \mathrm{ha}$. The significant improvement in growth parameters might be a consequence of the increased plant height, dry matter accumulation and crop growth rate. Similar findings were also illustrated by Yadav et al., (2010) and Singh et al., (2008) reported significantly higher growth parameters were obtained with increase in irrigation frequency. A proper supply of moisture with irrigation letting an increased growth and development of the crop plants got evident in the form of higher plant height, dry matter accumulation and crop growth rate. Such increased trends with irrigation frequency were also reported by Kumar et al., (2000). The nutrient levels had favourable effect on plant growth over control treatment that results better nutrient availability and number of metabolic processes taking place in the plant body, which in turn are affected by a variety of inherent and environmental factors to which plant is exposed that results more root dry weight, number of nodules per plant and nodule dry weight/plant (Chauhan et al., 2002). The balanced fertilization of crop may be ascribed to the effect of $\mathrm{N}$ on root development, energy transformation and metabolic processes of the plant, which in term resulted in greater translocation of photosynthates towards the sink development. This result was in conformity with Dongarkar et al., (2005). The supply of $\mathrm{N}$ compared to controlled plot is particularly important for its numerous roles in energy transfer and enhance the uptake of other important cations which results more plant growth and development (Garnayak et al., 2000). The recommended nutrient application made higher nutrients available to plants resulted in to more plant height, shoot biomass accumulation and crop growth rate (Ghanbahadur et al., 2006). The results also revealed higher available nutrients at prime vegetative growth of the crop at higher fertility levels as plant height, shoot biomass accumulation and crop growth rate and varied sharply and maintaining higher leaf area index which might have resulted higher photosynthetic activity at higher fertility levels (Kumar and Kumar, 2008).

\section{Yield attributes and yield}

The number of branches of hybrid mustard was significantly influenced due to various irrigation and nitrogen levels. At 50 DAS the maximum number of branches (6.0) was recorded with $\mathrm{IW} / \mathrm{CPE}=1.2$ followed by IW/CPE $=1.0$ and the lowest number of branches (4.6) was obtained with IW/CPE $=0.8$. The highest number of branches (9.7) at $60 \mathrm{DAS}$ was found with IW/CPE $=0.8$ followed by $\mathrm{IW} / \mathrm{CPE}=1.2$ and the least was recorded with $\mathrm{IW} / \mathrm{CPE}=1.0$ (8.7). At $90 \mathrm{DAS}$ number of branches was recorded the highest (11.0) with $\mathrm{IW} / \mathrm{CPE}=0.8$ followed by IW/CPE $=1.2$ and least (9.4) was noticed under IW/CPE $=1.0$. At harvest stage maximum number of branches (11.2) was recorded under $\mathrm{IW} / \mathrm{CPE}=1.2$ followed by $\mathrm{IW} / \mathrm{CPE}=1.0$ and the minimum (9.7) was observed with IW/CPE $=0.8$. Among the nitrogen doses, number of branches at 30 DAS was recorded the branches (7.3) with $120 \mathrm{~kg} \mathrm{~N} / \mathrm{ha}$ followed by $80 \mathrm{~kg} \mathrm{~N} / \mathrm{ha}$ and lowest branches (2.8) was obtained with 40 $\mathrm{kg} \mathrm{N} / \mathrm{ha}$. At 60 DAS number of branches was recorded the highest (12.9) with $120 \mathrm{~kg} \mathrm{~N} / \mathrm{ha}$ followed by $80 \mathrm{~kg} \mathrm{~N} / \mathrm{ha}$ and least was 
recorded with $40 \mathrm{~kg} \mathrm{~N} / \mathrm{ha}$ (7.0). The variation in number of branches at 60 DAS due to nitrogen doses was $59.26 \%$ to $84.29 \%$. At 90 DAS number of branches was recorded the highest (13.4) with $120 \mathrm{~kg} \mathrm{~N} /$ ha followed by $80 \mathrm{~kg} \mathrm{~N} / \mathrm{ha}$ and least (8.2) was recorded with $40 \mathrm{~kg} \mathrm{~N} / \mathrm{ha}$. The variation in number of branches at 90 DAS due to nitrogen doses was 42.55 to $63.41 \%$. At harvest stage number of branches was found the highest (13.7) with $120 \mathrm{~kg} \mathrm{~N} /$ ha followed by $80 \mathrm{~kg}$ $\mathrm{N} / \mathrm{ha}$ (9.7) and the lowest (8.2) was recorded with $40 \mathrm{~kg} \mathrm{~N} / \mathrm{ha}$. The variation in plant height due to nitrogen doses was 42.55 to $67.07 \%$. The maximum number of siliqua per plant (204) was recorded with application of IW/CPE $=1.2$ and $120 \mathrm{~kg} \mathrm{~N} /$ ha followed by IW/CPE $=0.8$ and $120 \mathrm{~kg} \mathrm{~N} / \mathrm{ha}$ and the lowest was recorded (81) with $\mathrm{IW} / \mathrm{CPE}=1.0$ and 40 $\mathrm{kg} \mathrm{N} / \mathrm{ha}$. Among the irrigation treatments, number of seeds per siliqua was recorded the highest (15) with IW/CPE=1.2 followed by IW/CPE $=1.0$ and the lowest number was obtained with IW/CPE $=0.8$ (13). Numbers of seeds per siliqua of hybrid mustard was significantly influenced by nitrogen doses. Among the nitrogen doses, Numbers of seeds per siliqua was found the highest (16.1) with $120 \mathrm{~kg} \mathrm{~N} / \mathrm{ha}$ followed by $80 \mathrm{~kg} \mathrm{~N} / \mathrm{ha}$ and least (12) was obtained with $40 \mathrm{~kg} \mathrm{~N} / \mathrm{ha}$. The variation in number of seeds per siliqua due to nitrogen doses was $15 \%$ to $34.17 \%$. The combined effect of irrigation levels and nitrogen doses on test weight of hybrid mustard was found significant. The maximum test weight ( $4.2 \mathrm{~g})$ was noticed with combined application of IW/CPE $=1.0$ and $120 \mathrm{~kg} \mathrm{~N} / \mathrm{ha}$ followed by IW/CPE $=1.2$ and $120 \mathrm{~kg} \mathrm{~N} / \mathrm{ha}$ and the lowest was recorded $(3.2 \mathrm{~g})$ with IW/CPE $=0.8$ and $40 \mathrm{~kg} \mathrm{~N} / \mathrm{ha}$. Irrigation and nitrogen levels had significant effect on seed and biological yield of hybrid mustard. The maximum seed yield $2016 \mathrm{~kg} / \mathrm{ha}$ was achieved in IW/CPE $=1.0$ with $120 \mathrm{~kg}$ nitrogen/ha followed by the treatment IW/CPE $=1.2$ with the same dose of nitrogen/ha and the minimum was noted with the irrigation treatment of IW/CPE $=1.2$ with $40 \mathrm{~kg}$ nitrogen/ha. The maximum biological yield $6908 \mathrm{~kg} / \mathrm{ha}$ was registered in IW/CPE $=0.8$ with $120 \mathrm{~kg}$ nitrogen/ha followed by the treatment IW/CPE=1.0 with the same dose of nitrogen/ha and the least yield was noted with the irrigation treatment of IW/CPE $=1.2$ with $40 \mathrm{~kg}$ nitrogen/ha. Under IW/CPE $=1.2$ irrigation treatment nitrogen response was less with the increasing levels of nitrogen from $40 \mathrm{~kg}$ to $120 \mathrm{~kg} / \mathrm{ha}$ but nitrogen response was maximum under IW/CPE $=1.0$ rather than IW/CPE $=0.8$ irrigation treatment. It might be due to application of right time irrigation scheduling enhanced availability of soil moisture and nutrients altogether these might have created a favourable growing condition for the crop, enhanced branching and boosted siliquae formation in the branches that results more yield attributes and yield (Kumar et al., 2000). Parmar et al., 2016) revealed that number of siliqua per plant and seed yield of mustard were increased significantly with optimum amount of application of irrigation water which resulted in higher moisture availability during crop growth period of mustard. Availability of soil moisture helped to maintain better plant water status and soil thermal regime during crop growing period while at the same time lowered down soil mechanical resistance, leading to higher root growth. This may be ascribed to overall improvements in vigour and crop growth. Since all essential plant nutrients, its incorporation in soil promotes rapid vegetative growth and branching, thereby increasing the sink size in terms of flowering, fruiting and seed setting. The improved overall growth and profused branching owing to $160 \mathrm{~kg} \mathrm{~N}+60 \mathrm{~kg} \mathrm{~S} / \mathrm{ha}$ application coupled with transport of photosynthates towards reproductive structures on the other hand, might have increased the yield attributes (Singh and Pal, 2011). 
Table.1 Effect of irrigation levels and nitrogen doses on plant height of hybrid mustard

\begin{tabular}{|c|c|c|c|c|}
\hline \multirow[t]{2}{*}{ Treatment } & \multicolumn{4}{|c|}{ Plant height (cm) } \\
\hline & 30 DAS & 60 DAS & 90 DAS & At harvest \\
\hline I1N1 & 26 & 133 & 140 & 139 \\
\hline I1N2 & 31 & 142 & 147 & 148 \\
\hline I1N3 & 32 & 145 & 151 & 152 \\
\hline I2N1 & 32 & 137 & 141 & 142 \\
\hline I2N2 & 37 & 138 & 143 & 144 \\
\hline I2N3 & 36 & 147 & 155 & 157 \\
\hline I3N1 & 28 & 139 & 142 & 143 \\
\hline I3N2 & 32 & 145 & 149 & 150 \\
\hline I3N3 & 37 & 149 & 153 & 155 \\
\hline SEm ( \pm ) I X N & 0.56 & 0.51 & 0.545 & 0.53 \\
\hline $\operatorname{LSD}(P=0.05)$ I X N & 1.89 & 1.71 & 1.94 & 2.01 \\
\hline SEm ( \pm$)$ N X I & 0.50 & 0.44 & 0.65 & 0.77 \\
\hline $\operatorname{LSD}(P=0.05)$ N X I & 1.98 & 1.81 & 1.70 & 1.37 \\
\hline
\end{tabular}

Where, $\left[\mathrm{I}_{1}\left(\mathrm{IW} / \mathrm{CPE}\right.\right.$ ratio=0.8); $\mathrm{I}_{2}\left(\mathrm{IW} / \mathrm{CPE}\right.$ ratio=1.0); $\mathrm{I}_{3}\left(\mathrm{IW} / \mathrm{CPE}\right.$ ratio=1.2); $\mathrm{N}_{1}\left(40 \mathrm{~kg} \mathrm{~N}^{-1}\right) ; \mathrm{N}_{2}\left(80 \mathrm{~kg} \mathrm{~N}^{-1}{ }^{-1}\right) ;$ $\left.\mathrm{N}_{3}\left(120 \mathrm{~kg} \mathrm{~N} \mathrm{ha}^{1}\right)\right]^{-}$

Table.2 Effect of irrigation levels and nitrogen doses on dry matter accumulation of hybrid mustard

\begin{tabular}{|c|c|c|c|c|}
\hline \multirow{2}{*}{ Treatment } & \multicolumn{4}{|c|}{ Dry matter accumulation $\mathbf{( g / \mathbf { m } ^ { 2 } )}$} \\
\hline & 30 DAS & 60 DAS & 90 DAS & At harvest stage \\
\hline I1N1 & 53.3 & 282.5 & 535.2 & 560.7 \\
\hline I1N2 & 77.7 & 363.3 & 709.4 & 757.3 \\
\hline I1N3 & 124.0 & 542.3 & 919.3 & 994.9 \\
\hline I2N1 & 45.3 & 307.1 & 426.9 & 478.8 \\
\hline I2N2 & 65.4 & 360.5 & 560.9 & 623.9 \\
\hline I2N3 & 107.3 & 455.1 & 967.2 & 1015.9 \\
\hline I3N1 & 70.9 & 306.4 & 644.6 & 698.6 \\
\hline I3N2 & 82.1 & 475.7 & 778.1 & 807.9 \\
\hline I3N3 & 98.4 & 567.3 & 1084.9 & 1114.4 \\
\hline SEm ( $)$ & & & & \\
\hline I X N & 0.457 & 1.538 & 2.172 & 5.392 \\
\hline N X I & 0.582 & 1.253 & 0.968 & 5.884 \\
\hline LSD (P=0.05) & & & & \\
\hline I X N & 1.651 & 5.104 & 6.899 & 18.760 \\
\hline N X I & 1.370 & 5.518 & 8.165 & 17.843 \\
\hline
\end{tabular}

Where, $\left[\mathrm{I}_{1}\left(\mathrm{IW} / \mathrm{CPE}\right.\right.$ ratio=0.8); $\mathrm{I}_{2}\left(\mathrm{IW} / \mathrm{CPE}\right.$ ratio=1.0); $\mathrm{I}_{3}\left(\mathrm{IW} / \mathrm{CPE}\right.$ ratio=1.2); $\mathrm{N}_{1}\left(40 \mathrm{~kg} \mathrm{~N}^{-1}\right) ; \mathrm{N}_{2}\left(80 \mathrm{~kg} \mathrm{~N}^{-1}\right)$; $\left.\mathrm{N}_{3}\left(120 \mathrm{~kg} \mathrm{~N} \mathrm{ha}^{-1}\right)\right]$ 
Table.3 Effect of irrigation levels and nitrogen doses on crop growth rate (CGR) of hybrid mustard

\begin{tabular}{|c|c|c|}
\hline \multirow[t]{2}{*}{ Treatment } & \multicolumn{2}{|c|}{ Crop growth rate $\left(\mathrm{g} / \mathrm{m}^{2} / \mathrm{day}\right)$} \\
\hline & 30-60 DAS & 60-90 DAS \\
\hline I1N1 & 7.6 & 8.4 \\
\hline I1N2 & 9.5 & 11.5 \\
\hline I1N3 & 13.9 & 12.6 \\
\hline I2N1 & 8.7 & 4.0 \\
\hline I2N2 & 9.8 & 6.7 \\
\hline I2N3 & 11.6 & 17.1 \\
\hline I3N1 & 7.9 & 11.3 \\
\hline I3N2 & 13.1 & 10.1 \\
\hline I3N3 & 15.6 & 17.3 \\
\hline SEm ( \pm ) I X N & 0.32 & 0.41 \\
\hline $\operatorname{LSD}(P=0.05)$ I X N & 1.11 & 1.42 \\
\hline $\operatorname{SEm}( \pm)$ N X I & 0.34 & 0.43 \\
\hline $\operatorname{LSD}(P=0.05)$ N X I & 1.06 & 1.37 \\
\hline
\end{tabular}

Where, [I $\mathrm{I}_{1}\left(\mathrm{IW} / \mathrm{CPE}\right.$ ratio=0.8); $\mathrm{I}_{2}$ (IW/CPE ratio=1.0); $\mathrm{I}_{3}\left(\mathrm{IW} / \mathrm{CPE}\right.$ ratio=1.2); $\mathrm{N}_{1}\left(40 \mathrm{~kg} \mathrm{~N}^{-1}\right) ; \mathrm{N}_{2}(80 \mathrm{~kg} \mathrm{~N}$ ha $\left.\left.{ }^{1}\right) ; \mathrm{N}_{3}\left(120 \mathrm{~kg} \mathrm{~N} \mathrm{ha}^{-1}\right)\right]$

Table.4 Effect of irrigation levels and nitrogen doses on number of branches of hybrid mustard

\begin{tabular}{|c|c|c|c|c|}
\hline \multirow{2}{*}{ Treatment } & \multicolumn{4}{|c|}{ Number of branches } \\
\hline I1N1 & 30 DAS & 60 DAS & 90 DAS & $\begin{array}{c}\text { At harvest } \\
\text { stage }\end{array}$ \\
\hline I1N2 & 2.6 & 7.3 & 9.3 & 9.3 \\
\hline I1N3 & 4.3 & 8.7 & 10.0 & 10.3 \\
\hline I2N1 & 6.7 & 13.0 & 13.7 & 14.0 \\
\hline I2N2 & 2.3 & 6.3 & 7.3 & 7.3 \\
\hline I2N3 & 5.3 & 8.0 & 8.7 & 9.0 \\
\hline I3N1 & 7.3 & 12.0 & 12.3 & 12.7 \\
\hline I3N2 & 3.3 & 7.3 & 8.0 & 8.0 \\
\hline I3N3 & 8.7 & 7.7 & 9.7 & 10.0 \\
\hline SEm $( \pm)$ I X N & 0.36 & 13.7 & 14.3 & 14.3 \\
\hline LSD $(\boldsymbol{P}=\mathbf{0 . 0 5}) \mathbf{I}$ X N & NS & 0.40 & 0.37 & 0.33 \\
\hline SEm $(\mathbf{\pm}) \mathbf{N}$ X I & 0.37 & NS & NS & NS \\
\hline LSD $(\boldsymbol{P}=\mathbf{0 . 0 5}) \mathbf{~ N ~ X ~ I ~}$ & NS & 0.54 & 0.26 & 0.43 \\
\hline NS & NS & NS & NS \\
\hline
\end{tabular}

Where, $\left[\mathrm{I}_{1}\left(\mathrm{IW} / \mathrm{CPE}\right.\right.$ ratio=0.8); $\mathrm{I}_{2}\left(\mathrm{IW} / \mathrm{CPE}\right.$ ratio=1.0); $\mathrm{I}_{3}\left(\mathrm{IW} / \mathrm{CPE}\right.$ ratio=1.2); $\mathrm{N}_{1}\left(40 \mathrm{~kg} \mathrm{~N}^{-1}\right) ; \mathrm{N}_{2}\left(80 \mathrm{~kg} \mathrm{~N}^{-1}\right)$; $\mathrm{N}_{3}\left(120 \mathrm{~kg} \mathrm{~N} \mathrm{ha}^{-1}\right)$ ] 
Table.5 Effects of irrigation levels and nitrogen doses on yield attributes of hybrid mustard

\begin{tabular}{|c|c|c|c|}
\hline Treatment & No. of siliqua per plant & No. of seeds per siliqua & Test weight (g) \\
\hline I1N1 & 87.7 & 11.3 & 3.2 \\
\hline I1N2 & 92.7 & 12.3 & 3.3 \\
\hline I1N3 & 195.3 & 15.3 & 3.8 \\
\hline I2N1 & 80.7 & 12.0 & 3.3 \\
\hline I2N2 & 102.0 & 14.3 & 3.7 \\
\hline I2N3 & 169.3 & 16.0 & 4.2 \\
\hline I3N1 & 94.0 & 12.7 & 3.3 \\
\hline I3N2 & 122.3 & 15.3 & 3.7 \\
\hline I3N3 & 204.0 & 17.0 & 4.0 \\
\hline SEm ( \pm ) I X N & 1.01 & 0.26 & 0.02 \\
\hline $\operatorname{LSD}(P=0.05)$ I X N & 3.62 & NS & 0.06 \\
\hline SEm ( \pm ) N X I & 1.24 & 0.17 & 0.00 \\
\hline $\operatorname{LSD}(P=0.05)$ N X I & 3.13 & NS & 0.08 \\
\hline
\end{tabular}

Where, $\left[\mathrm{I}_{1}\left(\mathrm{IW} / \mathrm{CPE}\right.\right.$ ratio=0.8); $\mathrm{I}_{2}$ (IW/CPE ratio=1.0); $\mathrm{I}_{3}$ (IW/CPE ratio=1.2); $\mathrm{N}_{1}\left(40 \mathrm{~kg} \mathrm{~N}^{-1}{ }^{-1}\right) ; \mathrm{N}_{2}(80 \mathrm{~kg} \mathrm{~N}$ $\left.\left.\mathrm{ha}^{-1}\right) ; \mathrm{N}_{3}\left(120 \mathrm{~kg} \mathrm{~N} \mathrm{ha}^{-1}\right)\right]$

Table.6 Seed yield of hybrid mustard influenced by irrigation levels and nitrogen management

\begin{tabular}{|c|c|c|c|c|}
\hline $\begin{array}{c}\text { Nitrogen levels } \\
(\mathbf{k g} / \mathbf{h a})\end{array}$ & \multicolumn{4}{|c|}{ Seed yield (kg/ha) } \\
\cline { 2 - 5 } & Irrigation levels & & \\
\hline & IW/CPE=0.8 & IW/CPE=1.0 & IW/CPE=1.2 & Mean \\
\hline $\mathbf{4 0}$ & 1003 & 1198 & 924 & 1041 \\
\hline $\mathbf{8 0}$ & 1327 & 1603 & 1572 & 1501 \\
\hline $\mathbf{1 2 0}$ & 1783 & 2016 & 1918 & 1906 \\
\hline Mean & 1371 & 1606 & 1471 & \\
\hline & Irrigation $(\mathrm{I})$ & Nitrogen $(\mathrm{N})$ & I X N & N X I \\
\hline SEm ( \pm () & 10.3 & 7.61 & 14.9 & 17.8 \\
\hline LSD (P=0.05) & 41.5 & 23.7 & 52.9 & 46.8 \\
\hline
\end{tabular}

Where, $\left[\mathrm{I}_{1}\left(\mathrm{IW} / \mathrm{CPE}\right.\right.$ ratio=0.8); $\mathrm{I}_{2}\left(\mathrm{IW} / \mathrm{CPE}\right.$ ratio=1.0); $\mathrm{I}_{3}\left(\mathrm{IW} / \mathrm{CPE}\right.$ ratio=1.2); $\mathrm{N}_{1}\left(40 \mathrm{~kg} \mathrm{~N}^{-1}\right) ; \mathrm{N}_{2}\left(80 \mathrm{~kg} \mathrm{~N}^{-1}\right)$; $\left.\mathrm{N}_{3}\left(120 \mathrm{~kg} \mathrm{~N} \mathrm{ha}^{-1}\right)\right]$ 
Table.7 Effect of irrigation levels and nitrogen doses on biological yield of hybrid mustard

\begin{tabular}{|c|c|c|c|c|}
\hline \multirow{3}{*}{$\begin{array}{l}\text { Nitrogen levels } \\
\quad \text { (kg/ha) }\end{array}$} & \multicolumn{4}{|c|}{ Biological yield (kg/ha) } \\
\hline & \multicolumn{4}{|c|}{ Irrigation levels } \\
\hline & $\mathrm{IW} / \mathrm{CPE}=0.8$ & $\mathrm{IW} / \mathrm{CPE}=1.0$ & $\mathrm{IW} / \mathrm{CPE}=1.2$ & Mean \\
\hline 40 & 4514 & 4757 & 4139 & 4470 \\
\hline 80 & 4764 & 5034 & 5361 & 5053 \\
\hline 120 & 6908 & 6620 & 6347 & 6625 \\
\hline \multirow[t]{2}{*}{ Mean } & 5395 & 5470 & 5282 & \\
\hline & Irrigation (I) & Nitrogen $(\mathrm{N})$ & I X N & N X I \\
\hline SEm $( \pm)$ & 2.91 & 2.30 & 4.37 & 5.04 \\
\hline LSD $(P=0.05)$ & 11.7 & 7.18 & 15.3 & 14.0 \\
\hline
\end{tabular}

Where, $\left[\mathrm{I}_{1}\left(\mathrm{IW} / \mathrm{CPE}\right.\right.$ ratio=0.8); $\mathrm{I}_{2}\left(\mathrm{IW} / \mathrm{CPE}\right.$ ratio=1.0); $\mathrm{I}_{3}\left(\mathrm{IW} / \mathrm{CPE}\right.$ ratio=1.2); $\mathrm{N}_{1}\left(40 \mathrm{~kg} \mathrm{~N}^{-1}\right) ; \mathrm{N}_{2}\left(80 \mathrm{~kg} \mathrm{~N}^{-}\right.$ $\left.\left.{ }^{1}\right) ; \mathrm{N}_{3}\left(120 \mathrm{~kg} \mathrm{~N} \mathrm{ha}^{-1}\right)\right]$

The higher values of yield attributes is the result of higher nutrient availability resulted in better growth and more translocation of photosynthates from source to sink (Piri et al., 2011). Therefore, it is evident from the result that nitrogen at higher dose promoted the production of siliquae per plant, which might have resulted from more growth of the crop plants along with production of more number of branches per plant with application of higher nitrogen dose (Sharma and Kumar, 1992). From this result, it is evident that nitrogen fertilization at higher rate influenced more seed formation in siliqua. It may be attributed to the fact that seed size of mustard remained almost uniform across different treatments (Singh and Srivastava, 1986). As seed yield is the resultant outcome of the effect of various growth and yield parameters, it expression was observed with their integrated influence. Balanced supply of essential nutrients to Indian mustard increased their availability, acquisition, mobilization and influx into the plant tissues increased and finally improved growth attributes and yield components and finally the yield. These results are in agreement with the findings of Singh et al., (2004). The increase in seed and biological yield under adequate nutrient supply might be ascribed, mainly due to balanced nutrition and increased photosynthesis, dry matter accumulation. These results are in conformity with those of Sharma et al., (2003). Reager et al., (2006) from Bangladesh stated that seed yield of mustard crop was enhanced due to application of $120 \mathrm{~kg} \mathrm{~N} / \mathrm{ha}$ which was statistically at par with nitrogen rate of $160 \mathrm{~kg} / \mathrm{ha}$.

On the basis of present investigation it can be concluded that the application of irrigation based on IW/CPE ratio along with combination of nitrogen may prove the most beneficial and remunerative to hybrid mustard for enhancing growth, yield attributes and yield in new alluvial soils of West Bengal, India.

\section{References}

Bharati, V., Prasad, U.K. and Singh, J.P. 2003. Irrigation and sulphur on yield and nutrient uptake of Indian mustard. Journal of Farming Systems Research and Development 8 (1): 97-98.

Bhari, N.R, Siag, R K. and Mann, P.S. 2000. Response of Indian mustard (Brassica juncea) to $\mathrm{N}$ and $\mathrm{P}$ on Torripsamments of north-western Rajasthan. Indian Journal of Agronomy 45: 746-51.

Chauhan, D.R., Ram, M. and Singh, I. 2002. Response of Indian mustard to irrigation and fertilization with various sources and levels of sulphur. Indian Journal of 
Agronomy 47 (3): 422-426.

Dongarkar, K.P., Pawar, W.S, Khawale, V.S., Khutate, N.G. and Gudadhe, N.N. 2005. Effect of nitrogen and sulphur on growth and yield of mustard (Brassica juncea L.). Journal of Soils and Crops 15: 163-67.

Garnayak, L.M., Singh, N.P., Singh, S. and Paikaray, R.K. 2000. Influence of irrigation and nitrogen on growth, yield and nutrient uptake by late sown Brassica oilseeds. Indian Journal of Agronomy 45: 371-78.

Ghanbahadur, M.R. and Lanjewar, B.K. 2006. Influence of sowing dates, irrigation levels and mulching on nutrient uptake and yield of mustard cv. ACN-9. Journal of Soils and Crops 16 (1): 158164.

GOI, 2018. Agricultural Statistics at a Glance. Agricultural Statistics Division, Department of Agriculture and Cooperation and Farmers Welfare, Ministry of Agriculture, GOI, New Delhi.

Kumar, A. and Kuma, R.S. 2008. Crop growth rate and developmental characteristics of Indian mustard var Vardan to varying levels of nitrogen and sulphur. Indian Journal of Agricultural Research 42: 112-15.

Kumar, D., Singh, S., Sharma, S.N. and Shivay, Y.S. 2000. Relative efficiency of urea and dicyandiamide-blended urea on mustard (Brassica juncea) varieties. Indian Journal of Agronomy 45: 17983.

Kumar, V., Ghosh, B.C., Bhat, R. and Karmakar, S. 2000. Effect of irrigation and fertilizer on yield nutrient uptake and water use efficiency on mustard [(Brassica juncea L.) Czerni \& Cosson] on . Acid Laterite soil. Journal of Oil Seeds Research 17(1): 117-121.

Malagoli, P, Laine, P., Rossato, L. and Ourry, A. 2005. Dynamics of nitrogen uptake and mobilization in field grown winter oilseed rape (Brassica napus) from stem extension to harvest. Annuals of Botany 95: 853-61.

Parmar, B.S., Patel, M.M., Patel, J.C., Patel, D.M., Patel, G.N. 2016. Enhance mustard [Brassica juncea (L.) Czern and Coss] productivity through sprinkler irrigation under north Gujarat conditions. Research on Crops 17 (1): 63-67

Piri, I., Nik, M.M., Tavassoli, A. and Rastegaripour, F. 2011. Effect of irrigation intervals and sulphur fertilizer on growth analyses and yield of Brassica juncea. African Journal of Microbiology Research 5(22): 36403646.

Reager, M.L, Sharma, S.K. and Yadav, R.S. 2006. Yield attributes, yield and nutrient uptake of Indian mustard (Brassica juncea) as influenced by nitrogen levels and its split application in arid western Rajasthan. Indian Journal of Agronomy 51: 213-16.

Sharma, G., Sutaliya, R., Prasad, S. and Sharma, M.L. 2003. Effect of irrigation and intercropping system on growth, yield and quality of mustard and linseed. Journal of Crop Research 25(3): 579-581.

Sharma, O.K. and Kumar, A. 1992. Effect of nitrogen fertilizer under different irrigation scheduling on production potential and economics of mustard. Fertilizer News 37: 37-41.

Singh, S.P. and Pal, M.S. 2011. Effect of integrated nutrient management on productivity, quality, nutrient uptake and economics of mustard (Brassica juncea). Indian Journal of Agronomy 54(4): 381-387.

Singh, A.K., Singh, S.N, Singh, O.P, Khan, M.A. 2008. Quality of Indian mustard (Brassica juncea L.) as affected by nitrogen and sulphur fertilizers in a 
nutrient deficient soil. Indian Journal of Agricultural Biochemistry 21: 39-41.

Singh, A. and Meena, N.I. 2004. Effect of nitrogen and sulphur on growth, yield attributes and seed yield of mustard (Brassica juncea) in eastern plains of Rajasthan. Indian Journal of Agronomy 49 (3): 186-188.

Singh, B.N. and Srivastava, S.P. 1986. Effect of irrigation and nitrogen fertilization on growth and yield of mustard in mid hills of Meghalaya. Indian Journal of Agronomy 31(2): 135-138.
Singh, S.P and Pal, M.S. 2011. Effect of integrated nutrient management on productivity, quality, nutrient uptake and economics of mustard (Brassica juncea). Indian Journal of Agronomy 56: $381-387$

Yadav, R.P., Tripathi, M.L. and Trivedi, S.K. 2010. Yield and quality of Indian mustard (Brassica juncea) as influenced by irrigation and nutrient levels. Indian Journal of Agronomy 55(1): 56-59.

\section{How to cite this article:}

Debashis Bindhani, S.B. Goswami, Amit Kumar, Gaurav Verma and Pratishruti Behera. 2020. Growth, Yield attributes and Yield of Indian Mustard [Brassica juncea (L.) Czern \& Coss] as Influenced by Irrigation and Nitrogen Levels. Int.J.Curr.Microbiol.App.Sci. 9(07): 1735-1746. doi: https://doi.org/10.20546/ijcmas.2020.907.200 